\title{
大都市の既成住宅地における住宅地整備要件に関する研究 一世田谷区の建物利用を視点としで一
}

\section{FACTORS TO FORM DWELLING AREA IN BUILT-UP HOUSES AREA}

-from view of building-Use in Setagaya ward-

藍澤 宏*, 柴田崇史**, 津田麻子***

Hiroshi AIZAWA, Takashi SHIBATA and Asako TSUDA

\begin{abstract}
In a built-up houses area in a large cities,site partition,high rising,high density of buildings and so on have brought about through renewal of housing and reorganization is on-going.

The purpose of this study is to grasp built-up houses area in view of building use based on block unit,and lastly to suggest what to do for improvement of dwelling area.As the research method,we classify dwelling area from view of building use, and find relation between its classifications and factors such as locational conditions, laws and regulations, and so on.

In conclusion:the purpose of use zone in force isn't reflected on what built-up houses areas are in terms of land and building use.In the near future,categories of use zone will be detailed much more,but it is still neccessary to consider locational conditions and form of buildings in view of group. unit and include them to regulation and guidance for preservative improvement in built-up housing area.
\end{abstract}

keyword:metropolitan area, built-up houses area, block unit,use zone, building use

大都市，既成住宅地，街区単位，用途地域，建物利用

\section{1. 研究の目的と方法}

\section{(1)研究の目的}

本編は、前報 ${ }^{1)}$ に引続き、建物利用の侧面から既成住 宅地整備の要件を求めていく。前報では土地利用の変容 過程を用途地域における利用規制、住宅用途と他用途と の混在状況から住宅地としての保全整備上の問題点を抽 出した。その結果、(1)住宅系用途地域指定の内、用途規 制の有効性を持つのは第 1 種住居専用地域指定のみであ り、第 2 種住居専用地域指定 - 住居地域指定 - 近隣商業 地域指定の規制効果はその性格が類似してきていること、 (2)土地利用種目構成で地区 ${ }^{2)}$ を類型化した結果、既成住 宅地は「住宅系－商業系」軸、「居住地－非居住地」軸、「未 開発一開発既存」檕とで区分されること、(3)現在の法規制 は土地利用の規制では効果があるものの変化の方向性を 規定するものとはなっていないこと等を明らかにした。 前報を含め、土地利用に関しては、これまでに多くの研 筧が出されてきた。しかし、近年の既往研究でも指摘さ
れている通り、高度化・集積化の高まる都市的な土地利 用においては、平面的な土地利用計画のみではなく、立 体的・空間的に建物を考虑した立体的な利用構成につい て検証することが必要なこととされている。しかしなが ら、これまでにこれらを視点として、都心 3 区を中心と した都心居住論や商業・業務を中心的な用途とした地域 についての研究 ${ }^{3)}$ は数多くなされているものの、住宅用 途を中心とした既成住宅地についての検証は、その多く が特定事例における建物を分析するにとどまっている。 特定の地域を対象とし、綿密に調査することは固有の地 域条件を建物に反映させる上で非常に有意義であるが、 一方、行政体を地域的な単位でみた建物状況把握は、地 域計画を広域的な側面から捉える上で重要なことである。 本来、既成住宅地においては、住宅地整備は既存の住 環境を維持・保全しつつ整備を行うことが必要であるが、 実際には、既存の法規制を遵守しつつも住宅の無秩序な 密集化や住宅種目之相容れない多種目の建物の混在等が
* 東京工業大学文教施設研究開発センター 教授・工博

** 東京工業大学 大学院生

*** NTTファシリティーズ 工修
Prof., Research and Development Center for Educational Facilities, Tokyo Institute of Technology, Dr. Eng. Graduate Student, Tokyo Institute of Technology NTT facilities, M. Eng. 
進捗しているのが現状である。

そこで、本研究では、既成住宅地の建物利用を行政単 位という広域的観点から捉える必要性から、地域分析単 位を居住条件の均一性を保持・維持すると考えられる一 定幅の道路に囲まれた街区“) とし、街区単位に建物群の 類型設定を行い、広域における建物現況把握の手法の提 示を行う。また、街区による建物群類型とその規定要因 との対応・行政域における地理的な類型の粼接状況およ びその圈域構造から建物群の特徽と課題を把握し、既成 住宅地の整備要件を求めることを目的とする。

\section{(2)研究の方法}

既成住宅地の位置付け、建物利用区分の設定、建物の 状況の把握方法、及び研究の手順は以下に示す通りであ る。

(1)研究対象地域である既成住宅地の位置付けを次の様に 行う。まず、既成住宅地は既成市街地内で土地利用が住 宅地を中心になされている区域とする。既往の研究等か ら既成市街地の定義として、「住宅やその他の建築物、道 路等の開発によって、ほぼすへての土地が既に都市的活 動に利用されている区域 5 」とされている。本研究ではこ の定義を充足し、かつ土地利用が住宅地を中心になされ ている区域を既成住宅地としている。しかしながら、既 成市街地の中でも土地利用の用途別利用内容は、住宅地、 商業地、工業地等が主要なものであり、公園・緑地等が その中に介在して存在している。地域全体が一つの用途 で利用される場合は極く僅かであり住商混在地、住工混 在地などの混在形態で住宅地は形成されている。そこで、 本研究では、住宅地混在地全体を研究対象地とし取扱う。 (2)建物利用区分は次の様に設定した。本論文で用いたテ

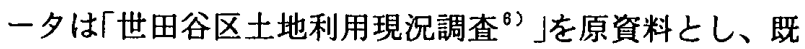
成住宅地の住宅系建物利用を基軸に再編したものである。 原資料は土地利用現況調查土地建物用途分類記載内容を 大分類 2 (宅地、非宅地)、中分類11 (公共系 - 住居系 - 商 業系・工業系・農業系(以上宅地)、空地系・公園系・交 通系・農地系・河川系・緑地系(以上非宅地))、小分類27 種目に区分されている。この分類を住宅系建物利用の混 在を基軸に 12 種目の建物利用に再区分し、原データとし た(表 1 )。

(3)街区単位の建物群の捉え方を次の様に行う。広域にお ける建物の現況を捉えるために分析単位として「街区」を 用いる。既成住宅地においては居住条件として空間の均 質性を求められることが多く、また、建物の集合の属性 を把握するにはある一定の領域が必要となるが、その最 小単位が街区」であると仮定したことによる。本研究で は、「街区」の上部構造としての建物の集合を建物群とし て捉える。尚、建物群の設定に当たっては、建物群に建 物 1 棟毎の属性を反映させるために以下の手順を踏んだ。
表 1 建物利用 12 種目

\begin{tabular}{|c|c|c|}
\hline 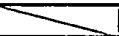 & 再編区分 & 現況啁查建物区分 \\
\hline$\frac{1}{2}$ 住宅系- & $\begin{array}{l}\text { 独立住宅 } \\
\text { 集合住宅 }\end{array}$ & $\begin{array}{l}\text { 尃用独立住宅 } \\
\text { 集合住宅 }\end{array}$ \\
\hline 3 & 官公庁施設 & 官公宁施設 \\
\hline 4 公共采 & 教育施設 & 教育文化施設 \\
\hline & \begin{tabular}{|l} 
厚生医療施設設 \\
供給処理施設
\end{tabular} & \begin{tabular}{|l} 
厚生医療施設 \\
供給処理施設
\end{tabular} \\
\hline$\dddot{7}$ & 住商併用建物 & 往商研角建物 \\
\hline 8 㶾業系・ & 專用商業施設 & 専用商業施設等 事務所建築物 \\
\hline & 遊興榗施設 & 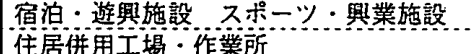 \\
\hline 11 工業采" & 専用工場等 & 守用工場・作業所 倉庫·運输関係施設 \\
\hline 12 その他 & その他 & 俊設建物 農林漁業施設等 \\
\hline
\end{tabular}

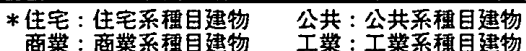

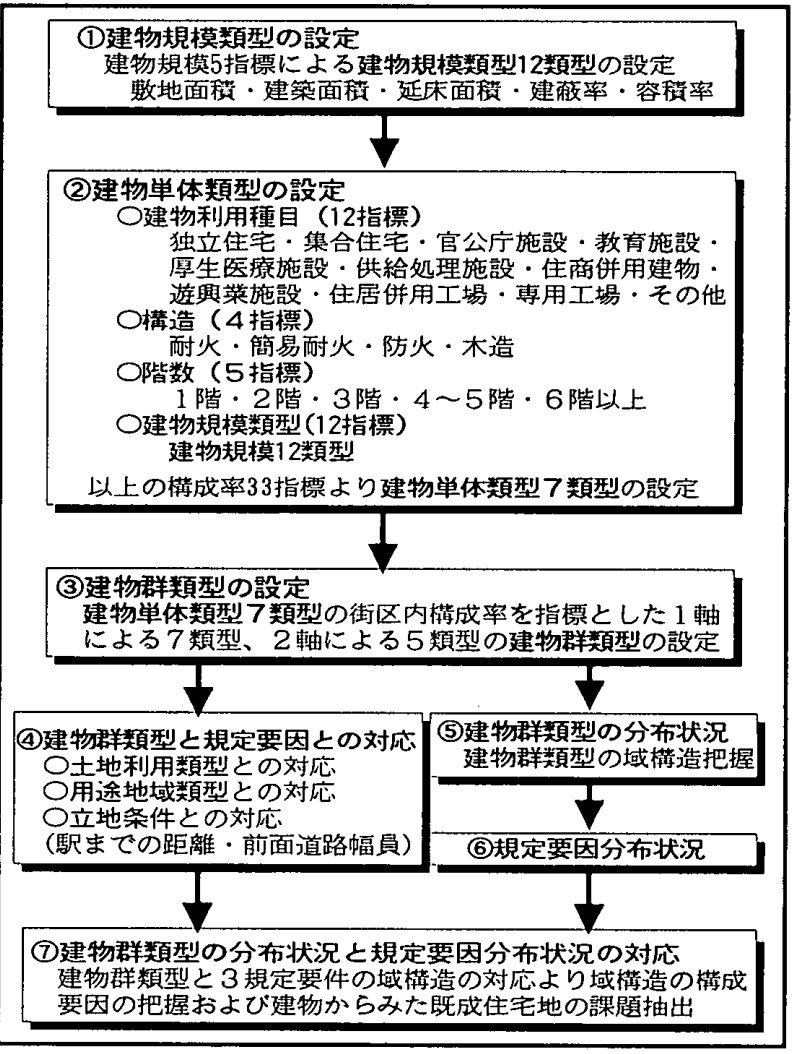

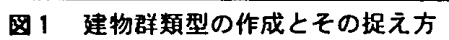

まず、第 1 に建物 1 棟単位に建物の規模による類型を 作成する。第 2 に建物 1 棟単位の建物特性を明らかにす るために、91年における建物利用種目、構造、階数、規 模を指標とした数量化正類を行い、建物単体の類型化を 行う。そして、第 3 に街区別の第 2 で求めた建物単体類 型の構成率と、総棟数を指標として、街区を単位とした 主成分分析を行い、街区単位の建物群の類型化を行う。 (4)この建物群類型の類型軸と建物の下部構造として土地 利用類型 ${ }^{7}$ 、法制度の側面から用途地域指定状況、立地 条件として交通条件や道路条件、等の規定要因との対応 により、その特徽を明らかにする。また、建物群類型分 布から既成住宅地における域構造を求め、域構造と規定 要因の分布状況とを対応させ、各要因の域構造に及ぼす 状況を求め、域構造の保全的計画要因を明らかにする。

以上により、既成住宅地における、住宅地の整借のた めの要件を導く。図 1 に建物群類型の捉え方を、図 2 に 


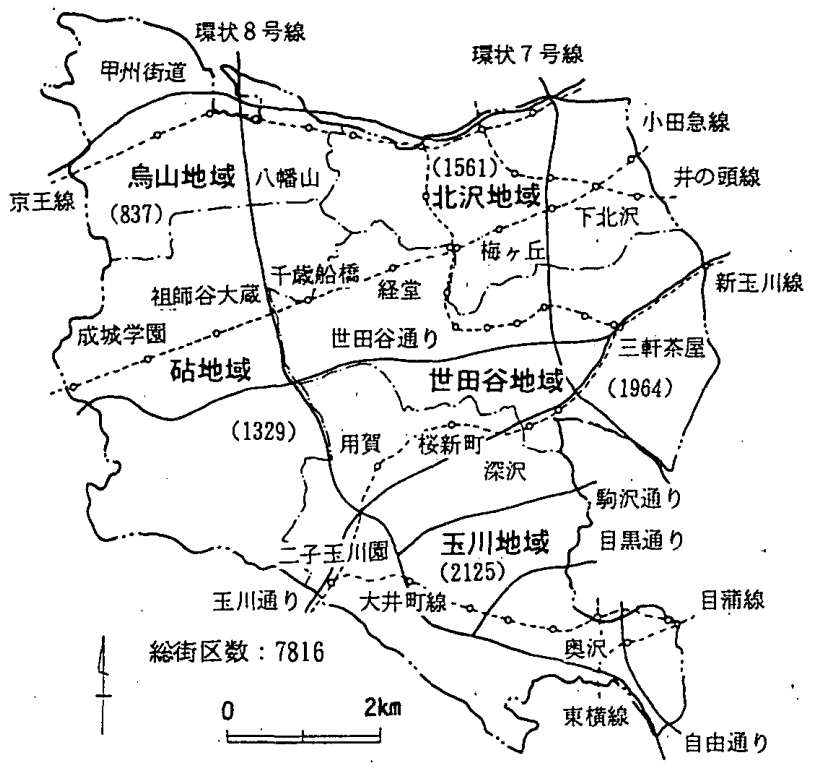

*（）内の数字は各地域の街区数を表す。

图2 研究対象地域概要

世田谷区の地域区分（砧、烏山、北沢、世田谷、玉川）、 鉄道、道路、主要地名を示す。

\section{（3）対象地の建物概要}

対象地である世田谷区全体の 1 棟単位にみた建物の概 要を表 2 及び表 3 に示す。

世田谷区全体の建物利用12種目別構成率は、'86年、 91年ともに独立住宅が約 $65 \%$ 、集合住宅が約 $18 \%$ 之建物 の利用内容は住宅系種目が $80 \%$ 以上を占めている。その 他の利用種目で比較的構成率の高い種目は、住商併用建 物が約 $8 \%$ 、専用商業施設、教育施設がそれぞれ約. $2 \%$ である。構成率の変化では、土地利用之同様に、独立住 宅の減少がー0.82\%と最も大きく、集合住宅の增加が+ $0.29 \%$ と増加しているのに対して、住商併用建物は -0 . 08\%と減少している。

世田谷区全体の建物の構造別構成率は、防火('86年57. $60 \% 、 91$ 年 $57.25 \%$ 、以下同じ)の㓶合が最も高く、次い で木造(21.90\%、20.29\%)となっており、まだまだ耐火 のレベルは低い。しかし、変化の傾向としては、木造が $-1.61 \%$ 、防火がー0.35\%と減少しているのに対して、 簡易耐火が+1.58\%、耐火が+0.37\%と増加しており、 耐火のレベルは高くなる方向である。

次に階数別の建物構成率は、2 階建て $77.70 \% 、 77.7$ 2\%)が最も高く、次いで 1階建て (13.05\%、11.97\%)と なっている。平均階数でみても約 2 階となっており、世 田谷区の建物は全体的にはまだまだ $1 \cdot 2$ 階建ての低層 の建物が主流である。しかし、変化の傾向としては、1 階建てはー $1.08 \%$ と減少しており、やや高層化していく 方向である。

建物の規模に関しては、平均建築面積は、約 $83 \mathrm{~m}^{2}$ であ り、平均延床面積は、約 $193 \mathrm{~m}^{2}$ である。また、平均敷地面
表 2 建物利用種目・構造・陵楼成率と変化(世田谷区全体)

\begin{tabular}{|c|c|c|c|c|}
\hline & 86 年 & 91年 & 贸化 \\
\hline 1 & 立 & 65.73 & 64.91 & $-.8 ?$ \\
\hline 建 & 合 & 17.76 & 18.37 & $.6 \mathrm{l}$ \\
\hline & 官公厅施設 & 24 & 25 & .01 \\
\hline 物 & 教育 施 & 1. 95 & 1.95 & .00 \\
\hline & 悬生医撩施設 & .38 & .39 & .01 \\
\hline 利 & 供給処理施設 & .18 & 21 & .03 \\
\hline & 住商併用建物 & 7.86 & 7.78 & -.08 \\
\hline 用 & 専用隌業施設 & 2.18 & 2.47 & .29 \\
\hline & 遊 興 業 施 設 & .20 & .21 & .01 \\
\hline 種 & 住工併角建物 & .79 & .75 & -.04 \\
\hline & 専 用 I 堨 等 & 1.71 & 1.80 & .09 \\
\hline 目 & ₹ & 1.02 & .92 & -.10 \\
\hline 2 & 耐 火 構 造 & 9.20 & 9.57 & .37 \\
\hline 構 & 簡易耐火構造 & 11.30 & 12.88 & 1.58 \\
\hline & 防 火 棈 造 & 57.60 & 57.25 & $-.3 j$ \\
\hline 造 & 木 造 棈 & 20.29 & 21.90 & -1.61 \\
\hline 3. & 1 階 建 & 13.05 & 11.97 & -1.03 \\
\hline 建 & 階 建 & 77.70 & 77.72 & .02 \\
\hline 物 & 階建 & 5.95 & 6.71 & .76 \\
\hline 皆 & 4、 5 階建 & 2. 78 & 3.05 & $2 i$ \\
\hline 㕷 & 6 階建て以上 & 52 & 56 & $0 \pm$ \\
\hline 数 & 平 均階 & 2.021 & 2.048 & 027 \\
\hline
\end{tabular}

※1各建物種目の植数/建物㣞棟数 * 100 単位 (\%) $※ 2$ 各構造の棟数/建物紇棟数 $* 100$ 単位 $(\%)$ ※3 各豥当階数の棟数/建物総棟数* 100 単位 $(\%)$ ※4変化とは’91年と'86年の搆成率の差による

表 3 建物平均規模（'91年、世田谷区全体）

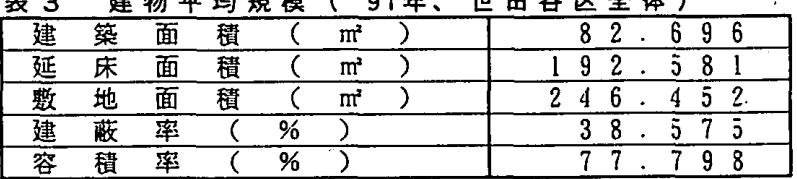

積は、約 $247 \mathrm{~m}^{2}$ となっており、平均建蔽率は約 $39 \%$ 、平均 容積率は約78\%となっている。

\section{2. 建物利用内容からみた建物単体類型の設定}

(1) 建物規模類型の設定

建物の規模による類型を設定するために、91年の建物 の「敷地面積」建築面積」「延床面積」建蔽率」容積率」を 指標として、156,528楝をサンプルとする因子分析を行っ た。因子分析の方法は、主成分法に上り因子解を得て、 バリマックス法により因子を回転した。指標の各軸に対 する固有值、固有べクトルおよび累積説明力を表 4 に示 す。固有值 1 以上となる 2 軸までを考察の対象とする。

1 軸では十側に「敷地面積」建築面皘」延床面皘」が寄与 表4 建物規模固有ベクトル

\begin{tabular}{|c|c|c|c|c|c|c|c|}
\hline 指 & 1 軸 & 2 軸 & & & 1 軸 & 2 軸 & 槙数 \\
\hline 数 地面 皘 & 745 & -.189 & & 1 類型 & 大 & 大 & 5973 \\
\hline 建築面積 & 931 & 145 & & 2 類型 & 大 & 中 & 2315 \\
\hline 延床面積 & 886 & 244 & & 3 類型 & 大 & 小 & 1290 \\
\hline 建 蔽 率 & -.057 & 920 & 建 & 4 類型 & 大中 & 大 & 4483 \\
\hline 容 積 率 & 175 & 916 & 物 & 5 類型 & 大中 & 中 & 3364 \\
\hline 固 有 值 & 2.409 & 1.634 & 規 & 6 類型 & 大中 & 小 & 2090 \\
\hline 累積寄与率 & .482 & .809 & 模 & 7 類型 & 中 & 大 & 14357 \\
\hline \multirow{2}{*}{\multicolumn{3}{|c|}{ 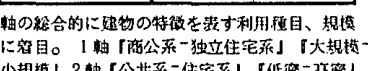 }} & 類 & 8 類型 & 中 & 中 & 36527 \\
\hline & & & 型 & 9 類型 & 中 & 小 & 14302 \\
\hline \multicolumn{3}{|c|}{ 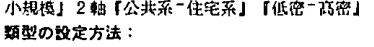 } & & 10 類型 & 小 & 大 & 6784 \\
\hline \multirow{2}{*}{\multicolumn{3}{|c|}{ 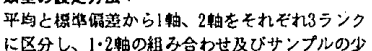 }} & & 11 類型 & 小 & 中 & 41462 \\
\hline & & & & 12 類型 & 小 & 小 & 23581 \\
\hline
\end{tabular}
ない顿型を合せることにより7数型を钧定

することより、建物の実際の大きさを表す「絶対的規模 大一小』軸として解釈できる。2 軸では十側に「建蔽率」 「容積薪」が寄与することより、建物の教地に対する割合 を表す『相対的規模大一小』軸として解釈できる。これ 
より得点値の平均および標準偏差を用いて、得点值の大 きい方から 1 軸を 5 ランクに、また 2 軸を 3 ランクに区 分した。このうち、1 軸は最も一侧の第 5 ランクのサン プル数が 0 のため、1 から4のランクを用いる。この 1 軸と 2 軸のランクの組合せにより 12 類型を設定した(表 5 )。

\section{(2)建物単体類型の設定}

建物 1 棟単位の類型を求めるために、建物の利用種目 に関する12指標、構造に関する4指標、階数に関する5指 標、(1)で求めた建物の規模に関する12指標の合計33指標 （表 6 )を用いて、156,528棟をサンプルとする数量化 III 類 を行った。この結果、カテゴリープロット図(図 3 )より、 1 軸は+侧に「6階以上」「4・5階」「耐火」規模 1 類型」が主 に寄与し、(利用種目では「商業系種目」「公共系種目」)が 寄与し、一侧に「独立住宅」「防火」「木造」「1階」「規模12類 型」規模 9 類型「規模 11 類型」が奇与することより主に建 物の形態を表わす軸、2 軸は+側に「規模 3 類型」供給処 理施設」「その他」が寄与し、一側に「規模10類型」規模 7 類型」住商併用建物」集合住宅」が寄与することより主に 敷地に対する建物の大きさを表わす軸と解釈できる。こ れよりサンプル得点值の平均および標準偏差を用いて、

表 6 建物単体類型指摽

\begin{tabular}{|c|c|c|}
\hline & & \\
\hline \multirow{2}{*}{ 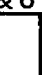 } & 1 & 独立住宅 \\
\hline & 2 & 集合住宅 \\
\hline \multirow[t]{2}{*}{ 利 } & 3 & 官公厅施歇 \\
\hline & 4 & 教育文化施設 \\
\hline \multirow[t]{2}{*}{ 用 } & 5 & 厚生医療施設 \\
\hline & 6 & 供給処理施設 \\
\hline \multirow[t]{2}{*}{ 種 } & 7 & 住商併用建物 \\
\hline & 8 & 専用商業施設 \\
\hline \multirow[t]{4}{*}{ 目 } & 9 & 遊興業施設等 \\
\hline & 10 & 住居併用工場 \\
\hline & 11 & 尃用工場等 \\
\hline & 12 & その他 \\
\hline & 13 & 酎火 \\
\hline & 14 & 簡易酎火 \\
\hline & $\begin{array}{l}15 \\
16\end{array}$ & $\begin{array}{l}\text { 防火 } \\
\text { 木造 }\end{array}$ \\
\hline
\end{tabular}

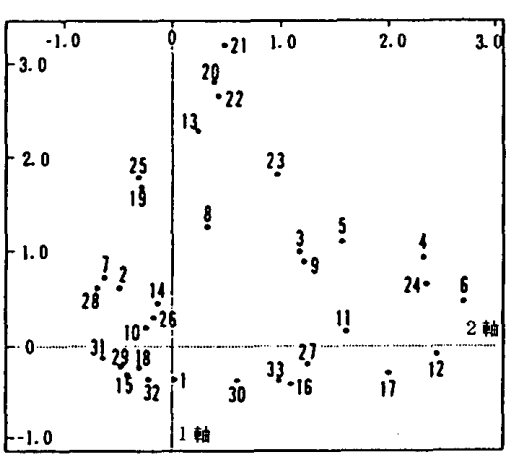

図3 カテコリープロット図 1 軸 (形的)

酎灭・高層・商公葲

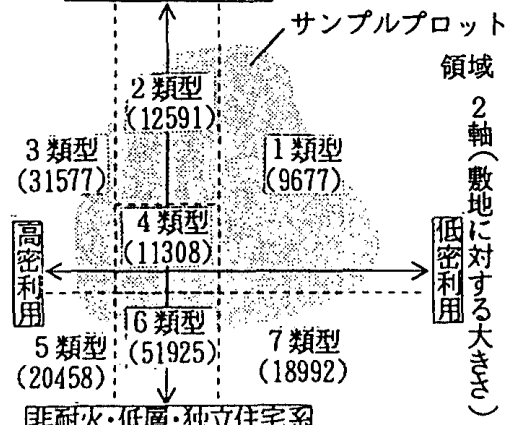
罒耐灭·低層·独亩住宅系 ※( )内はサンプル数を示す 図4 得点值の分布と類型設定

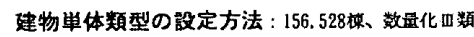

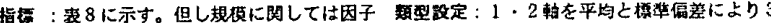

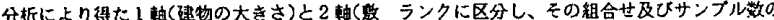
地に対する割合)の柤合せによる分颣を用いる。少ないものを合せることから７類型を歌定。

1 軸之 2 軸の各軸について得点值の大きい方から 3 ラン クに区分し、この 1、2 軸の組合せおよびサンプルの少 ない類型を合せることにより 7 類型を設定した（図 4 )。
3. 街区単位の建物群類型の設定と規定要因との対応 (1)建物単体類型の構成からみた建物群類型の設定 1) 区分軸の意味付け

利用種目、構造、階数、規模の視点で分類した建物の 街区単位の集合として建物群を捉える。このため、前節 で求めた建物単体 7 類型の構成率と建物の総棟数を指標 として、7,816街区をサンプル数とする主成分分析を行っ た。指標の各軸に対する固有值、固有ベクトルおよび累 積説明力を表 7 に示す。これより、1軸は十側に「建物単 体 1 類型」建物単体 2 類型」が寄与し、一側に「建物単体 6 類型」が寄与することより、建物群のボリュームと内容 を表す『大規模商公系一小規模独立住宅系』軸として解 釈できる。 2 軸は+側に「建物単体 3 類型」が寄与し、側に「建物単体 5 類型」が寄与することより、街区におけ る建物の集積度を表す『高密一低密』軸として解釈でき る。3 軸は+侧に「建物単体 1 類型」建物単体 2 類型」建 物単体 6 類型」建物単体 7 類型」が寄与し、一側に「建物 単体 4 類型」が寄与することより、『建物群の規模と密度 における特徵の有無を表す」軸として解釈できるが、こ れは 1 軸と 2 軸を組合せることにより考察することがで きる為、考察の対象から除外した。

2)建物群類型の設定

各街区の主成分得点値の平均值および標準偏差により、 得点値の大きい方から、1 軸に関しては建物群のボリュ 一ムと内容を表す大規模商公系の 1 類型から小規模独立 住宅系の 7 類型までを設定し、2 軸に関しては建物の集 積度を表す高密な 1 類型から低密な 5 類型までを設定し た(表 8 )。

(2)建物群類型と規定要因との対応

1)土地利用類型との対応

まず建物群のボリュームと内容を表わす 1 軸と土地利 用類型各軸との関連をみる。土地利用類型の 1 軸、『住 宅一商業』軸(図 5 )とはクラマー係数 ${ }^{8)}$ の值が0.0415 と かなり高い関連がみられる。その対応は土地利用が住宅 地中心のI 型では小規模独立住宅系の街区の割合が高く、 住商混在の II 型、商業地中心の III 型となるにつれて、大 規模商公系の街区の割合が高くなる。また土地利用類型 の 2 軸、『居住地一非居住地』軸(図 6 ) ともクラマー係 数の値が 0.0146 と関連がみられ、その対応は、居住地優 位の A 型から、居住地混在のB 型、非居住地のC 型とな るにつれて、小規模独立住宅系の街区から大規模商公系 の街区の割合が高くなる。さらに土地利用類型 3 軸、

「未開発一開発既存』軸(図7)ともクラマー係数の值が 0.0176 と関連がみられる。その対応をみると、開発可能 地の多い(1)型において小規模独立住宅系の建物群の割合 が高く、開発可能地の少ない(2)型において大規模商公系 の建物群の割合が高い。これより、建物群のボリューム 
表 7 建物群固有ベクトル

\begin{tabular}{|c|c|c|c|c|}
\hline \multicolumn{2}{|c|}{ 指 標 } & 1 軸 & 2 軸 & 3 軸 \\
\hline & 1 類 型 & .452 & -.329 & 224 \\
\hline 建 & 2 類 型 & 478 & 155 & 243 \\
\hline 物 & 3 類 型 & .001 & 727 & 161 \\
\hline 単 & 4 類 型 & .078 & .074 & -.761 \\
\hline 体 & 5 類 型 & 096 & -.562 & -.392 \\
\hline 類 & 6 類 型 & -.551 & -.102 & 234 \\
\hline 型 & 7 類 型 & -.357 & 063 & 266 \\
\hline & 容棟数 & -.347 & 056 & -.080 \\
\hline & 宥值 & 1.873 & 1.339 & 1.084 \\
\hline & 寄与率 & 234 & 401 & 537 \\
\hline
\end{tabular}

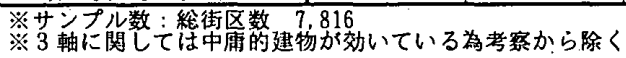

表 8 建物群類型の設定

\begin{tabular}{|c|c|c|c|c|c|c|c|}
\hline \multirow{3}{*}{1 軸 } & 1 類型 & 2 類型 & 3 類型 & 4 類型 & 5 類型 & 6 類型 & 7 類型 \\
\hline & 1146 & 553 & 879 & 1214 & 1635 & 1391 & 998 \\
\hline & \multicolumn{7}{|c|}{$\rightarrow$ 小規模独立住＝ } \\
\hline \multirow{3}{*}{2 軸 } & & 1 類型 & 2 類型 & 3 類型 & 4 類型 & 5 類型 & \\
\hline & & 1.489 & 1537 & 1854 & 1501 & 1435 & \\
\hline & \multicolumn{7}{|c|}{ 高密 } \\
\hline
\end{tabular}

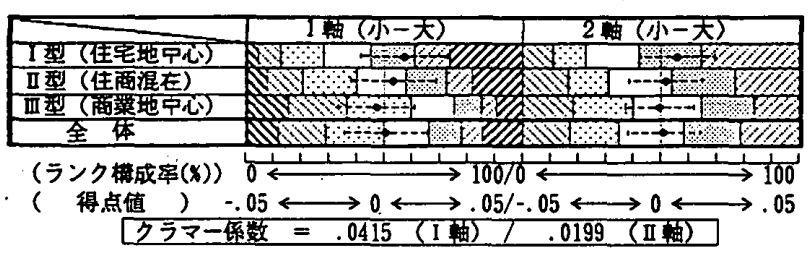

图5 建物群類型と土地利用類型 1 朝との対応

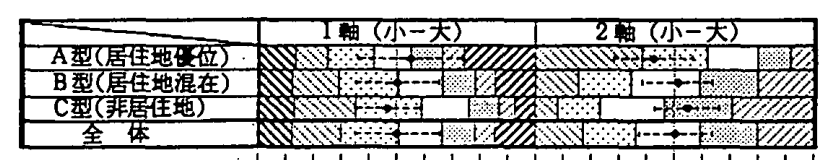

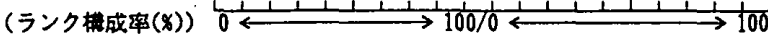

( 得点値) $\quad-.05 \longleftrightarrow 0 \longleftrightarrow .05 /-.05 \longleftrightarrow 0 \longleftrightarrow .05$

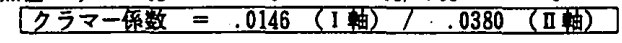

图6 建物群類型と土地利用類型 2 軸との対応

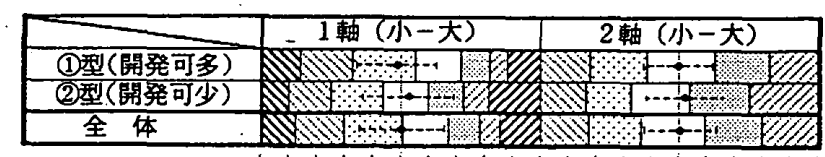

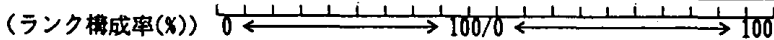

( 得点値) $\quad-.05 \longleftrightarrow 0 \longleftrightarrow .05 /-.05 \longleftrightarrow 0 \longleftrightarrow .05$

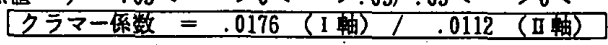

图 7 建物群類型と土地利用類型 3 軸との対応

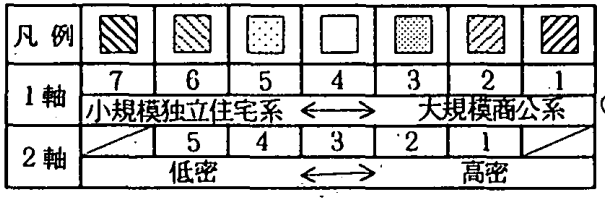

*以下、图8 10についても凡列同し。

表 9 用途地域固有ベトル

\begin{tabular}{|c|c|c|c|c|c|c|}
\hline 指 & 標 & 1 軸 & 2 軸 & 3軸 & 4 軸 & 5 軸 \\
\hline 1 種 住 & 尃 & -.764 & -.040 & 013 & -.040 & 014 \\
\hline 2 種住 & 專 & 478 & -.688 & -.129 & -.094 & .022 \\
\hline 住 & 居 & 306 & .637 & -.489 & -.114 & -.018 \\
\hline 近 隣 商 & 業 & 267 & .287 & .759 & -.126 & -.359 \\
\hline 商 & 業 & 140 & 170 & 222 & 254 & .869 \\
\hline 準 I & 業 & .055 & 018 & -.097 & 928 & -.313 \\
\hline 無 指 & 定 & 021 & .092 & -.331 & -.188 & -.130 \\
\hline 固 有 & 值 & 1.704 & 1.235 & 1.051 & 1.016 & 1.004 \\
\hline 累皘寄与 & & 243 & 420 & .570 & 715 & .859 \\
\hline
\end{tabular}

と内容は土地利用類型と一定程度の対応を示すことが明

らかとなった。しかし、土地利用類型 1 軸において住宅
地中心の I 型でも $20 \%$ 以上大規模商公系の建物群が形 成され、商業地中心の III 型でもおよそ30\%は小規模独立 住宅系の建物群が形成されている。

次に街区における建物の集積度を表す 2 軸と土地利用 類型各軸との関連をみる。土地利用類型の 1 軸『住宅一 商業』軸とはクラマー俰数の值が0.0199と高い関連がみ られる。その対応は土地利用が住宅地中心の I 型から、 住商混在の II 型、商業地中心の III 型となるにつれて、低 密な街区の割合から高密な街区の割合が高くなり、1 軸 の小規模独立住宅系の建物群から大規模商公系の建物群 の割合が高くなるのと同じような対応関係を示している。 また土地利用類型の 2 軸『居住地一非居住地』軸とはク ラマー係数の值が0.0380 とかなり高い関連がみられる。 その対応をみると、居住地優位の A 型から、居住地混在 のB型、非居住地のC型となるにつれて、高密な街区か ら低密な街区の割合が高くなる。1軸の建物群のボリュ 一ムと内容との対応から、A型からC型になるにつれて 大規模商公系の建物群の割合が高くなっており、非居住 地のC型において密度の低い公共系の建物群の割合が高 くなっているものと考えられる。土地利用類型 3 軸「未 開発一開発既存』軸との対応は、開発可能地の多い(1)型 において低密な建物群の割合が高く、開発可能地の少な い(2)型において高密な建物群の割合が高くなっている。 これより、1軸の建物群のボリュームと内容と同じよう に集積度も土地利用類型と一定程度の対応を示すことが 明らかとなった。しかし、土地利用類型 1 軸において住 宅地中心の I 型では建物群の集積度は 1 類型から 5 類型 までほぼ同じ割合で粡成されており偏りはみられない。

以上より、建物群類型と土地利用類型は一定程度の対 応は示すが、土地利用類型が住宅系であっても大規模商 公系の建物群や高密な建物群が形成されるといった問題 点が明らかとなった。すなわち、街区単位で建物群をみ ることにより土地利用だけでは明らかにできない形態に 関する問題を抽出できることが求められた。

2)用途地域指定状況との対応

(1)用途地域類型の設定

指定されている用途地域により街区を分類するために、 用途地域 7 指定（無指定を含む、住居系 3 指定、商業系 2 指定、工業系 1 指定)の構成率を指標として、7816街区を サンプルとする主成分分析を行った。指標の各軸に対す る固有值、固有ベクトルおよび累積説明力を表 9 に示す。 固有值が 1 以上となる 5 軸までの軸と指標との相関をみ ると、 4 軸以降は 4 軸は準工業、 5 軸は商業と特定の指 標が強く寄与するだめ、1 軸から 3 軸までを用いる。 1 軸では一側に「第 1 種住居専用地域(以下、第 1 種住専)」 が大きく寄与することより、第 1 種住専の指定の大小を 表す軸と意味つけられる。2 軸では十侧に「住居地域」商 業系用途地域」が寄与し、一侧に「第 2 種住居専用地域(以 
下、第 2 種住専)」が寄与することより、第 2 種住専一住 居地域、商業系用途地域の指定の軸之意味つけられる。 また、3 軸では十側に「商業系用途地域」が寄与し、一仪 に「住居地域」が奇与することより、商業系の指定－住居 地域の指定の糨と意味づけられる。これより、まず住宅 地を扱うといった視点から、住居系の 3 つの用途地域の みで棈成されている街区で 3 類型を設定し、次に、第 1 種住専の指定を視点に 1 軸を+とーの 2 ランクに区分し、 第 2 種住専の指定を視点に 2 軸を+とーの 2 ランクに区 分した。さらに、1、2 卌ともに+のランクについては、 住居地域の指定が多くかかっているのか、商業系の指定 が多くかかっているのかを判断するために 3 軸十と一の 2ランクに区分した。この 1 軸から 3 軸のランクの組合 せにより 8 類型を設定した(表10)。

\begin{tabular}{|c|c|c|c|c|}
\hline & & & & \\
\hline 類 & 型 & 型 & 容 & サンプル数 \\
\hline Yl類 & & 1 種住専のみ & & 3304 \\
\hline Y 2 類 & & 1 種住専と 2 種住専 & & 514 \\
\hline Y3 類 & & 2 種 住専のみ & & 1133 \\
\hline Y 4 類 & & 1 種 住 専と住 居、商業系 & & 617 \\
\hline Y5 類 & & 住 居のみ & & 560 \\
\hline Y 6 類 & & 2 種住専と住居、商業系 & & 542 \\
\hline Y7類 & & 住居と商業系、工業系 & & 397 \\
\hline Y8 類 & & 商業系 & & 749 \\
\hline
\end{tabular}

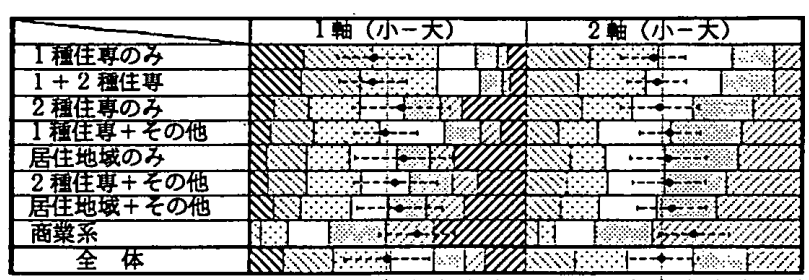

(ランク楼成率(X)) ( 得点值) $\quad .05 \longleftrightarrow 0 \longleftrightarrow .05 /-.05 \longleftrightarrow 0 \longleftrightarrow .05$ 万ラマー係数 $=.0305$ (I 䡩) $/ .0355$ (II䡩)

図8建物群類型と用途地域類型との対応

(2)用途地域類型との対応

まず建物群のボリュームと内容を表わす 1 軸と用途地 域類型との対応をみると(図 8 )、クラマー係数の值が0. 0305 とかなり高い関連がみられる。その対応は、第 1 種 住専が主な指定のY1・Y2・Y4類型、特に第 1 種住専の指定 のみで構成されているY1類型と第 1 種住専と第 2 種住専 の指定で構成されているY2類型では、小規模独立住宅系 の建物群の割合が他の類型と比べて、かなり高くなって いる。第 2 種住専、住居地域の指定のみで構成されてい るY3・Y5類型では、他の住居系混在類型に比へて、かなり 大規模商公系の建物群の割合が高くなっている。墑業系 の規制が主な指定のY8類型では、ほとんどが大規模商公 系の建物群となっており、小規模独立住宅系の建物群は 僅かとなっている。

次に街区における建物の集積度を表す 2 軸と用途地域 類型との対応をみると、1 軸と同様にクラマー係数の值 が0.0355とかなり高い関連がみられる。その対応は、Y1 類型からY8類型になる程、つまり住居系から商業系の規 制が強くなるに従って、高密な建物群の制合が高くなる。
特に商業系の規制が主な指定のY8類型では、50\%以上が 最も高密な 1 類型の建物群となっている。第 1 種住専の 指定のみ、第 1 種住専と第 2 種住専の指定、第 2 種住専 の指定のみで棈成されているY1からY3類型では、低密な 建物群の割合が高く、特に第 1 種住専の指定のみ、第 1 種住専と第 2 種住専の指定で棈成されているY1・Y2類型で は最も高密な 1 類型の建物群の割合も低くなっている。

以上より、建物群類型と用途地域指定状況之は関連が みられ、住居系の規制が強いほど集積度は低く抑えられ ている。また、第 1 種住専が主な指定である場合に大規 模商公系の建物群は形成されにくく、さらに第 1 種住専 のみ、もしくは第 1 種住専と第 2 種住専の組合せの指定 で構成されている場合に小規模独立住宅系の建物群が保 全されやすいという傾向がみられる。

3)立地条件との対応

街区と最寄り駅までの距離と街区前面道路幅員との関 連でみていく。

(1)駅までの距離との対応

駅までの最短距離により街区を $250 \mathrm{~m}$ 未霂、 $250 \mathrm{~m}$ 以上 $500 \mathrm{~m}$ 未満、 $500 \mathrm{~m}$ 以上 $750 \mathrm{~m}$ 未満、 $750 \mathrm{~m}$ 以上 $1000 \mathrm{~m}$ 未満、 $1000 \mathrm{~m}$ 以上の 5 つに分類し、建物群類型の $1 、 2$ 軸との 対応をみる(図 9 )。

まず建物群のボリュームと内容を表わす 1 軸との対応 をみると、クラマー係数の值は0.0086とあまり関連はみ られないが、駅までの距離が $250 \mathrm{~m}$ 未満の街区において、 小規模独立住宅系の建物群の割合が最も低く、大規模商 公系の建物群の割合が最も高くなっている。また、駅ま での距離が $750 \mathrm{~m}$ 以上 $1000 \mathrm{~m}$ 未満の街区において、小規模 独立住宅系の建物群の割合が最も高なっており、小規模 独立住宅系の建物群は駅から離れるに従いその割合は高 くなるが、1000 m以上になると形成されにくくなる傾向 がみられる。

次に街区における建物の集積度を表す 2 軸との対応を みると、クラマー係数の值が 0.0183 と高い関連がみられ

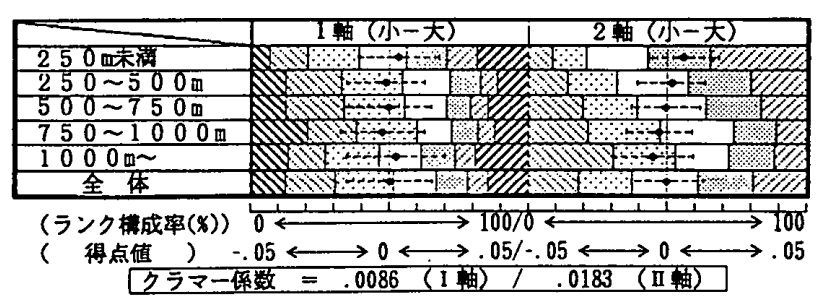

図9

建物群類型と駅までの距離との対応

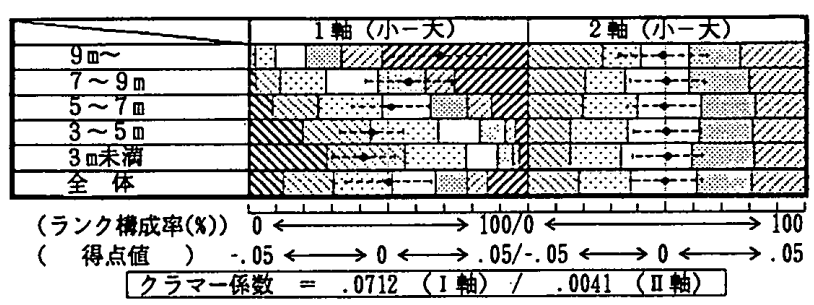

図10建物群類型と平均前面道路幅員との対応 
る。その対応は、駅からの距離が遠い街区になる ほよ゙、低密な建物群の割合がほぼ一定の割合で增 加し、高密な建物群の割合が減少する。ただし、 駅までの距離が $750 \mathrm{~m}$ 以上 $1000 \mathrm{~m}$ 末満の街区と、1 $000 \mathrm{~m}$ 以上の街区では高密な建物群の割合はほぼ同 じ值となっている。

以上より、駅までの距離は建物群の集積度と高 い関連がみられ、駅までの距離が遠くなるほど低 密な建物群となる傾向がみられる。

(2)前面道路幅員との対応

前面道路幅員の平均により、街区を $9 \mathrm{~m}$ 以上、 $7 \mathrm{~m}$ 以上 $9 \mathrm{~m}$ 未満、 $5 \mathrm{~m}$ 以上 $7 \mathrm{~m}$ 未満、 $3 \mathrm{~m}$ 以上 $5 \mathrm{~m}$ 未満、 $3 \mathrm{~m}$ 未満の 5 つに分類し、建物群類型 1、2 軸との対応をみる(図10)。

まず建物群のボリュームと内容を表わす 1 軸と の対応をみると、クラマー係数の值が0.0712とか なり高い関連がみられる。その対応は、前面道路 幅員の平均が狭くなるほど、大規模商公系の建物 群から小規模独立住宅系の建物群の割合が增加す る。前面道路幅員の平均が $9 \mathrm{~m}$ 以上の街区ではお よそ $80 \%$ が大規模商公系の建物群であり、最も大 規模商公系のレベルの高い 1 類型の建物群の割合 が50\%以上を占めている。前面道路幅員の平均が $5 \mathrm{~m}$ 未満になると、小規模独立住宅系の建物群の 割合が50\%を越え、大規模商公系の建物群の割合 は20\%以下となる。特に $3 \mathrm{~m}$ 未満の街区では、大 規模商公系の建物群の割合は僅かとなる。

次に街区における建物の集積度を表す 2 軸との 対応をみると、クラマー係数の值が 0.0041 とあま り関連はみられないが、前面道路幅員の平均が 9 $\mathrm{m}$ 以上の街区では高密な建物群、低密な建物群と もにその割合が高くなっている。

以上より、前面道路幅員は建物群のボリューム および内容と高い関連がみられ、前面道路幅員の 平均が狭くなるほど、小規模独立住宅系の建物群 の割合が高くなること、特に、平均が $9 \mathrm{~m}$ 以上の 街区では小規模独立住宅系の建物群は形成されに くく、平均が $5 \mathrm{~m}$ 未満の街区では一定の割合に維 持されることが示された。

\section{4. 既成住宅地の域搆造}

(1) 建物群類型各軸の分布状況 ${ }^{9}$

建物群類型 1、2 軸の分布状況をみる。まず建 图12 建物群類型 2 軸の類型分布

物群のボリューム之内容を表わす 1 軸の分布状況をみる と(図11)、全体的には、駅や都市計画道路を中心として 大規模商公系のレベルの最も高い1 類型の建物群が位置 し、その周りに 2 類型、3 類型の建物群が分布し、さら にその周囲に小規模独立住宅系の建物群が分布している。

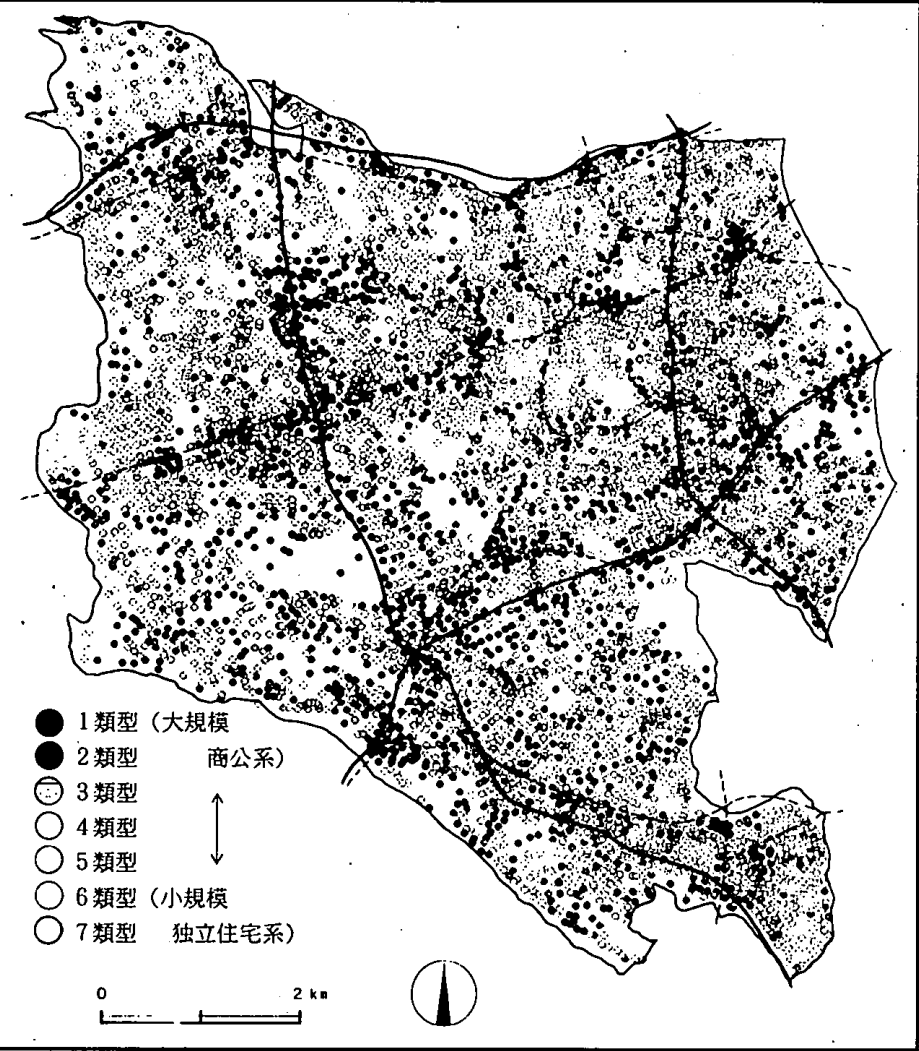

图11建物群類型 1 乹の類型分布

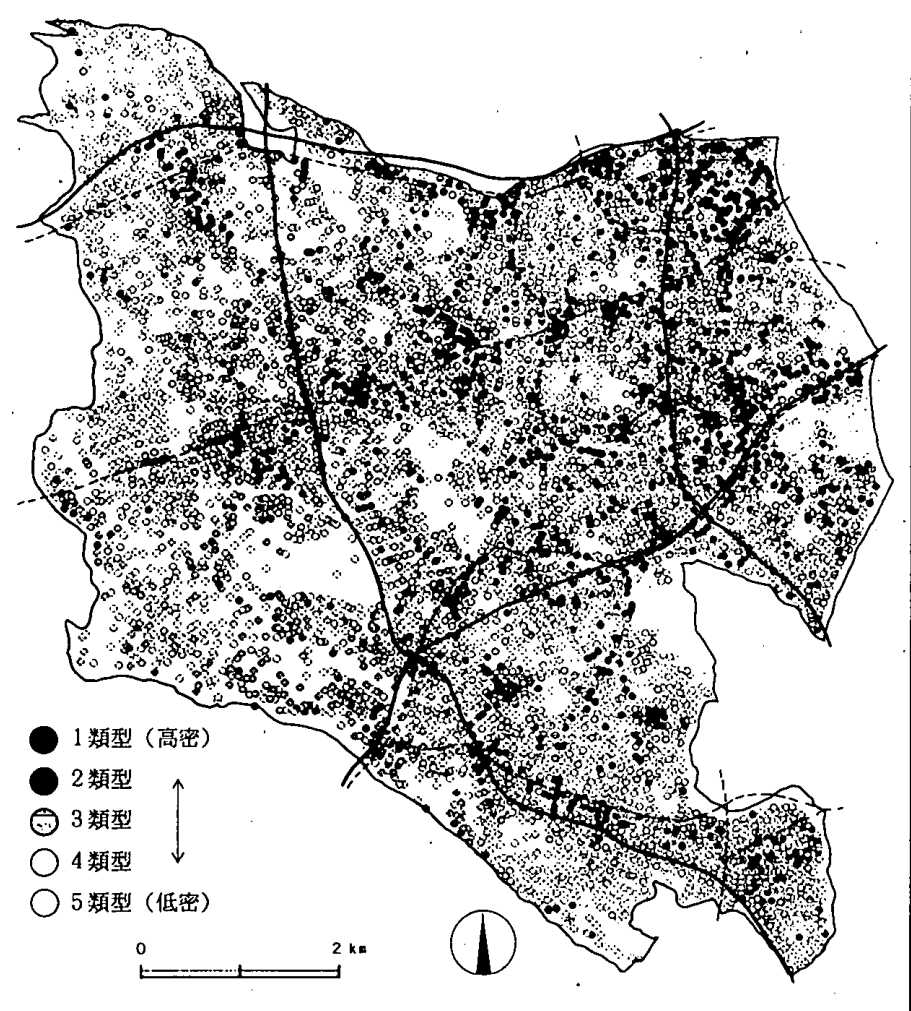

しかし、今後の開発地域である砧地域では、駅や都市計 画道路とは無関係に大規模商公系の建物群は位置し、小 規模独立住宅系の建物群と共に点在している。次に街区 における建物の集積度を表す 2 軸の分布状況をみると(図 12、、1 軸と同様に駅や都市計画道路の周辺に、高密化の 
進んだ建物群が位置し、その周囲を段階的に低密 な建物群が取り囲んで分布している。しかし、全 体的に区の北東部において高密であり、南西部に おいて低密となっている。

以上より建物群類型は 1 軸、 2 軸ともに類型間 に構造的な関連がみられることから、これらを組 合せることで、既成住宅地における建物群の域構 造を把握する。

\section{(2)既成住宅地における域構造}

既成住宅地における建物群の域構造を把握する ために、建物群のボリュームおよび内容をあらわ す 1 軸之建物の集皘度を表す 2 軸を組合せた類型 を設定した。設定方法は、1 軸に関しては 7 区分 を( 1 類型と 2 類型)、( 3 類型と 4 類型と 5 類型)、 ( 6 類型と 7 類型)の 3 区分に、また 2 軸に関して は 5 ランクを( 1 類型)、( 2 類型と 3 類型と 4 類型)、 (5 類型)の 3 区分にまとめ、このそれぞれ 3 区分 の組合せにより、a 類型から i 類型の合計 9 類型 を設定した(表11)。

この 9 類型の分布状況をみると(図13)、既成住 宅地では、a・b類型の大規模商公系で中高密な建物

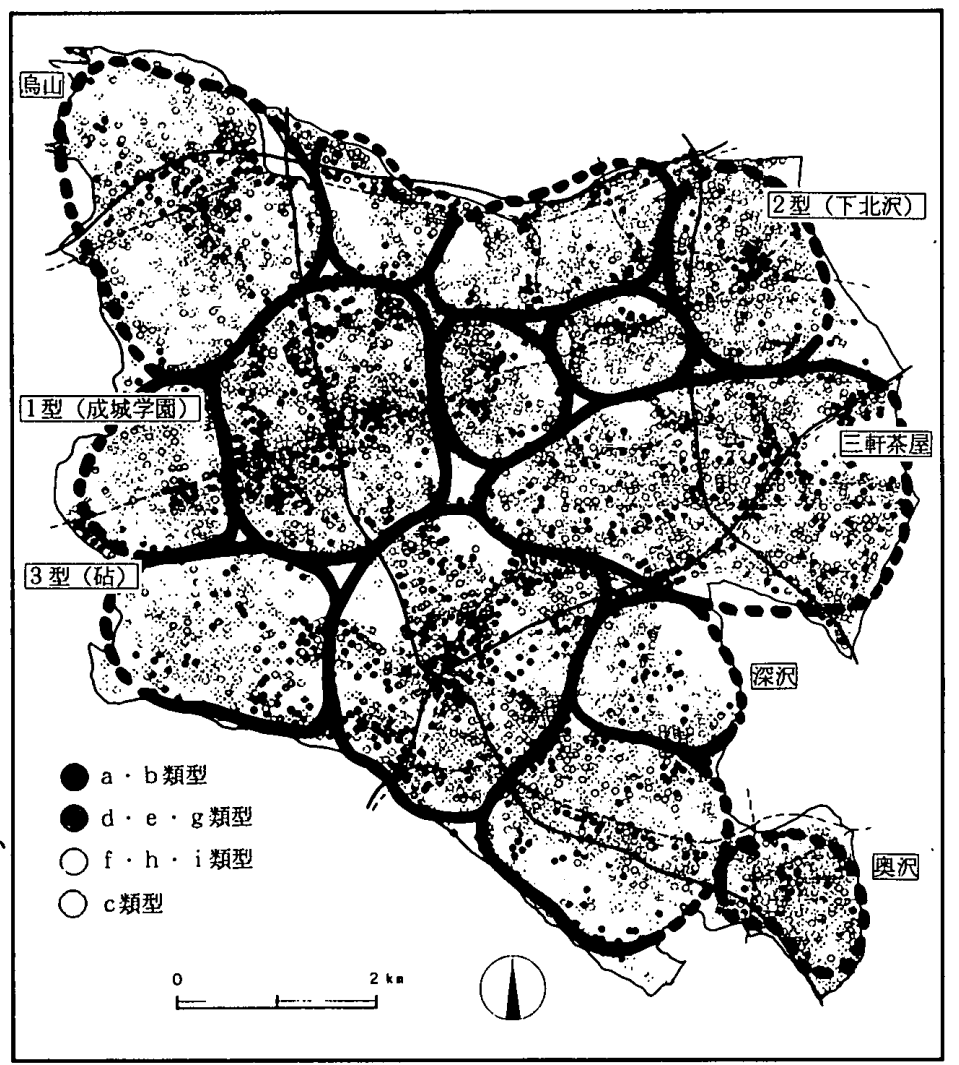

图13 建物群類型 1 - 2軸の類型分布
群が核となる圈域を形成していること、また、大規模商 公系で低密なc類型の建物群は公共系の要素が強く、公立 公園や、大規模公共施設のある街区に主に存在している ことがわかった。さらに、類型分布を詳細に考察すると、 その域構造として、

1 型：核を持つが住宅地の建物群構成が段階的でない

2 型：核を持ち住宅地の建物群構成が段階的である

3 型：核を持たないもの

以上の大きく 3 つのタイプが抽出される。

\begin{tabular}{|c|c|c|c|c|c|c|c|c|c|}
\hline & a 類型 & $\mathrm{b}$ 類型 & c 類型 & $d$ 類型 & $\mathrm{e}$ 類型 & $\mathrm{f}$ 類型 & $\mathrm{g}$ 類型 & $\mathrm{h}$ 類型 & $\mathrm{i}$ 類型 \\
\hline 1 軸 & 大 规 & 摸西 & 公系 & & 中 规 & & 小規相 & 独立住 & 宅系 \\
\hline 2 粙 & 高密 & 中密 & 低密 & 高密 & 中密 & 低密 & 高密 & 中篥 & 低密 \\
\hline
\end{tabular}

1 型は大規模商公系で中高密なa・b類型を核として、そ の周囲を中規模で低密なf類型や小規模独立住宅系で中低 密なん・i類型が取り囲む域構造であり、成城学園がこれに あたる。2 型は核である大規模商公系で中高密なa・b類型 と中規模で低密な類型や小規模独立住宅系で中低密なh $\cdot i$ 類型の間に中間的な中規模で中高密なd・e類型や小規模 独立住宅系で高密なg類型が位置する域構造であり、下北 沢がこれにあたる。また 3 型は大規模商公系で中高密な $\mathrm{a}$ •b類型が核としてのまとまりを示さない域構造であり、 砧や深沢にみられる。これらの3タイプの域棈造はそれ ぞれ、核の数や分散の程度によって様々な構造に変形し ている。具体的にみていくと、烏山では 1 型の域構造を 基本としているが、核であるa・b類型が分散し、その間に 中間的なd・e・g類型を形成している。奥沢、梅ケ丘、経堂 では 2 型の域構造を基本としているが、核となるa・b類型 が線状に分散し、これを取り囲む中間的なd・e・g類型も域 構造の境界部分に広がっている。これは、隣の域構造と 結びつく可能性を示している。二子玉川から用賀、桜新 町の新玉川線沿いにかけてと千歳船橋から祖師谷大葴、 八幡山の京王線沿いでは、2 型の域構造の核の分散がさ らに進んだ数個の域構造が結びついて、1つの大きな域 構造を構成している。三軒茶屋周辺は 1 つの大きな中心 から数本線状に広がった核をもち、大きな域構造を構成 している。行政域境界の部分は、南側のみ河川で界され ているため領域が形成されるが、他は別の行政界之接し ているため、境界設定は未確定として破線で示した。

以上より、既成住宅地は(1)核を持つが住宅地の建物群 構成が段階的でない構造(2核を持ち住宅地の建物群構成 が段階的な構造(3核を持たない構造の3タイプの域構造 を基本として、核の数や分散の程度によって変形した様 々な域構造で構成されている。

\section{（3）域構造の分布状沉}

域構造の形成要因を明らかにする為に、域構造と規定 要因の分布状況を対応させた。

まず駅および幹線道路の位置との対応をみると、核と なるa・b類型の建物群は駅や幹線道路を中心に分布してい る状沉が示される。また、砧や深沢など駅がない場合a・ 


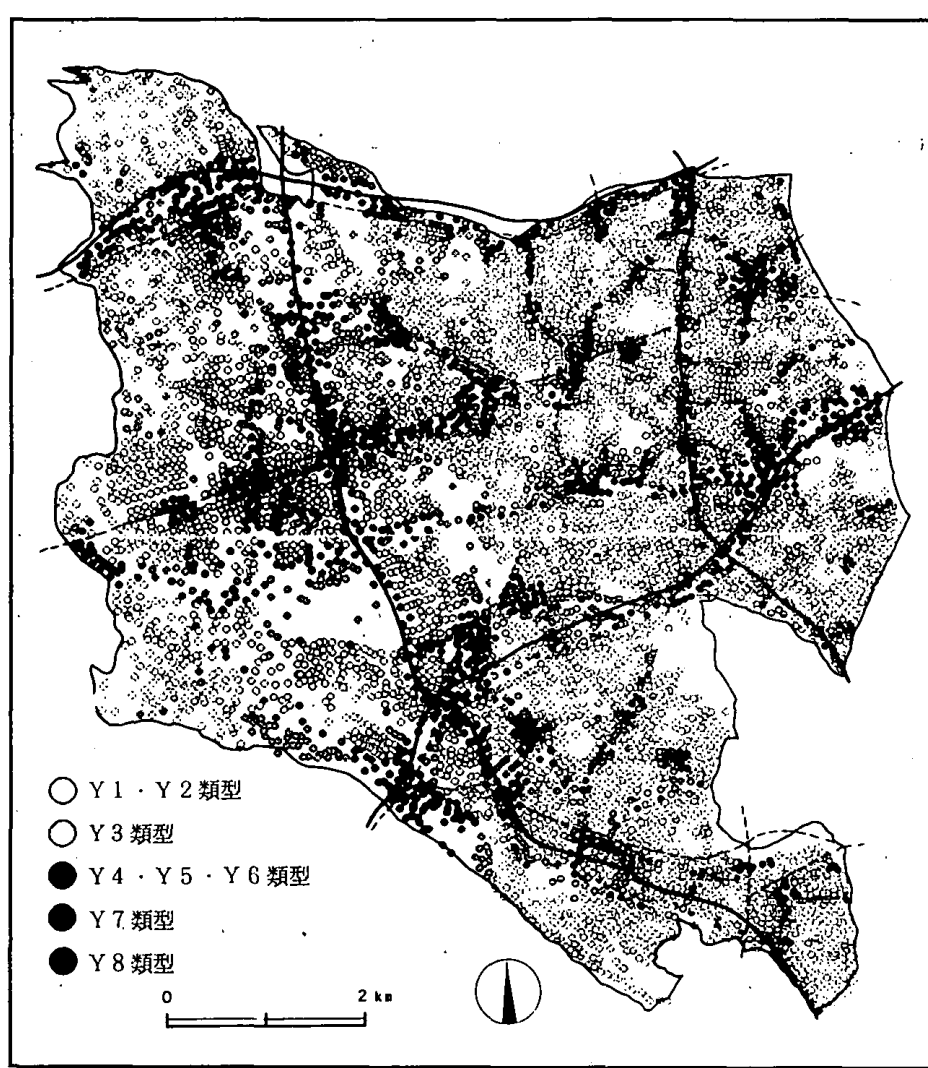

図14 用途地域類型の分布

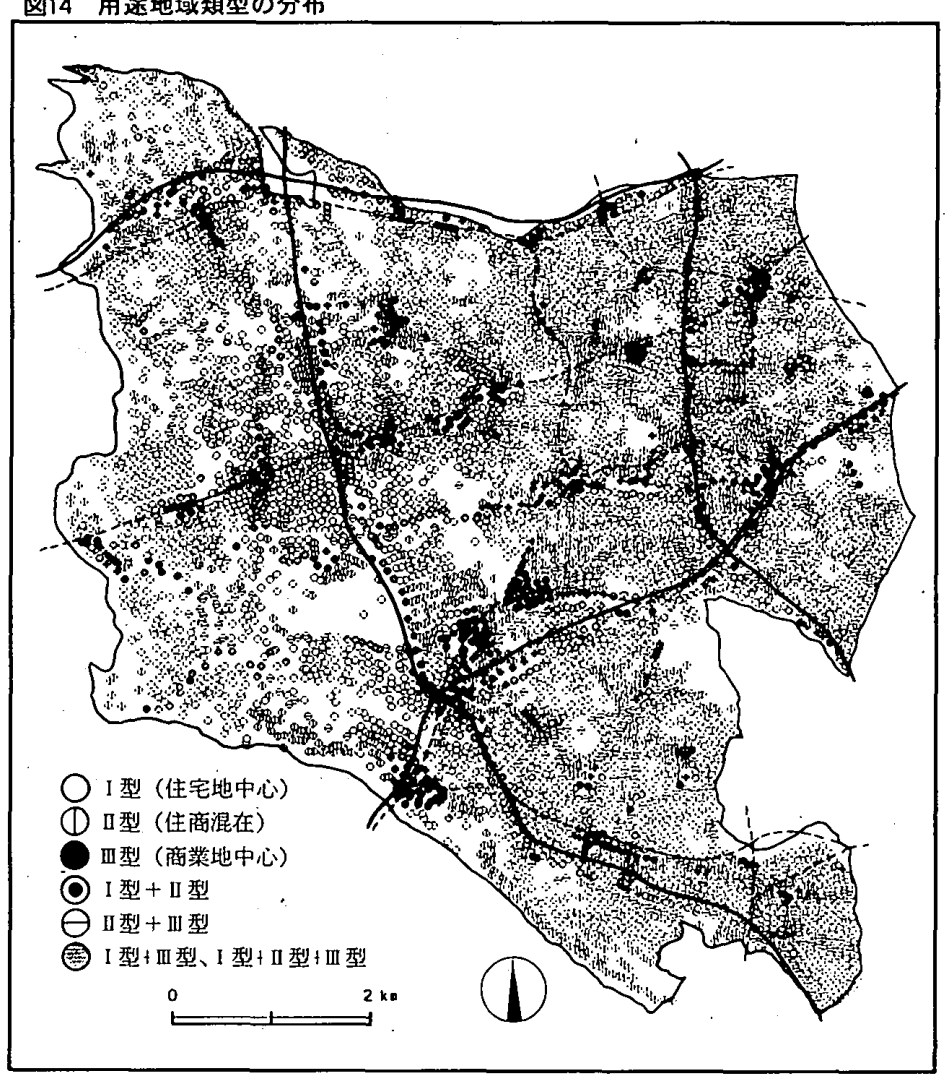

系の規制であるY8類型の街区にみられる。しかし、 核の分散が進んでいる域構造、例えば三軒茶屋や 干歳船橋から祖師谷大藏、八幡山の域構造の用途 地域指定状況をみる亡、商業系の規制のY8類型の 周囲を、第 1 種住専に関連のない住居系の規制の $Y 7 \cdot Y 6 \cdot Y 5 \cdot Y 3$ 類型が大きく取り囲んでおり、この街 区に核となるa・b類型が分散している。逆に、成城 学園や下北沢のようにまとまりのある核を持った 域㮃造の用途地域指定状況は、Y8類型の周囲を第 1 種住尃に関速したY1・Y2・Y4類型が大きく取り囲 むような指定状況となっている。すなわち住宅地 としてまとまりのある核をもった域構造は、第 1 種住専に関連した指定を商業系の指定の周辺にす ることで保全されており、間に他の住居系の規制 を指定すると、核のまとまりは崩れ、分散が進む 傾向にあることが明らかとなった。また、幹線道 路か駅を結んでいるところでの域構造は、三軒茶 荎や二子玉川から用賀、桜新町にかけてのように、 核が線状に広がっている。これは幹線道路沿いが 商業系の規制となっているためであると考えられ る。

さらに土地利用類型の分布との対応をみると、 土地利用類型 1 軸との対応は(図15)、成城学園や 下北沢のように、まとまりのある核を持った域構 造では、土地利用は商業地中心の开型の周囲を住 宅地中心の I 型が取り囲むような分布状況となっ ている。また、核の分散が進んでいる三軒茶屋や 二子玉川から用賀、桜新町にかけてでは、商業地 中心の III 型と住宅地中心の I 型の間に住商混在の 几 型が存在するような土地利用の分布状況となっ ている。つまり、土地利用の状況が商業地中心の II 型の周辺部に住宅地中心の I 型が存在する時に、 その上部棈造である建物群の域構造は、住宅地と してまとまりのある核を持ったものとして保全さ れているが、間に住商混在の II 型が存在する場合 は、核の分散が進む傾向が示された。土地利用類 型 2 軸、3 軸との対応については、建物群類型の 域構造とは直接的な関連はみられず、土地利用の 状況が居住地であるか非居住地であるかといった ことや、開発可能地が多いか少ないかといったこ 之は、上部構造である建物群の域構造にはあまり 影響を与えないことが明らかとなった。
図15 土地利用類型 1 朝の類型分布

b類型はまとまりを示さず、核を持たない域㯹造となって いる。すなわち、既成住宅地における建物群の域構造で は駅と幹線道路の構成が核の形成とその棈造に大きな影 響を与えていることが明らかとなった。

次に用途地域指定状況をみると（図14)、核は主に商業

\section{5.まとめ}

地域分析単位を「街区」と設定し、広域における建物 群を把握する方法を提示した。建物群の類型化を行い、 規定要因との対応、その地域構造、域構造と規定要因の 対応により、現在形成されている建物群からの問題点を 
抽出し、今後の課題を求めた。本研究で明らかになった 事柄を以下にまとめる。

(1)建物単体を利用種目、構造、階数、規模の視点で類型 化を行い、建物単体を区分する軸として、形態と敷地に 対する大きさを表す軸が得られた。さらに、設定した建 物単体類型を街区単位に類型化した結果、既成住宅地に おける建物群を区分する軸として、ボリューム、利用種 目および集積度の軸が得られ、形態に関しても把握でき ることを明らかにした。

(2)建物群類型と(1)土地利用類型の関連をみると、一定程 度の対応は示すが、土地利用類型が住宅系であっても大 規模商公系の建物群や高密な建物群が形成されていると いう課題が明らかとなった。また、(2)用途地域指定状況 の関連をみると、住居系の規制が強いほど集積度は低く 抑えられていること、すなわち、独立住宅系建物群を保 全するためには、用途地域の指定は第 1 種住居専用地域 か、第 1 種住居専用地域と第 2 種住居専用地域の組合せ のみ有効であることが明らかとなった。(3)立地条件の対 応からは、駅までの距離が遠くなるほど低密な建物群之 なる傾向がみられ、前面道路幅員の平均が狭くなるほど、 小規模独立住宅系の建物群の割合が高くなる。小規模独 立住宅系の建物群は平均が $9 m$ 以上の街区では形成されに くく、平均が $5 \mathrm{~m}$ 末満の街区では一定の割合に維持される こと等、が明らかになった。

（3）建物群類型の分布状況は主な傾向として、駅や都市計 画道路を中心に、大規模商公系の建物群が、また集積度 を表す高密な建物群が位置し、それぞれその周りを段階 的に、小規模独立住宅系の建物群や低密な建物群が取り 囲む分布状況となっていることが示された。

(4)既成住宅地は、大規模商公系で中高密な建物群を核と して、(1核を持つが住宅地の建物群構成が段階的でない 構造、(2)核を持ち住宅地の建物群構成が段階的な構造、 (3)核を持たない構造の大きく 3 タイプの域構造を基本と して、核の数や分散の程度によって変形した様々な域構 造で構成されていることが求められた。また、建物群の 域構造では駅と幹線道路の構成が、核の形成とその構造 に大きな影響を与えている状況が示された。さらに、用 途地域指定状況との対応では、核は主に商業系の規制の 街区にみられるが、第 1 種住居専用地域に関連のない住 居系の規制の街区にも分散している状況が示されだ。す なわち、住宅地としてまとまりのある核をむった域構造 は、第 1 種住居専用地域に関連した指定を商業系の指定 の周辺にすることで圈域が保全されていることが明らか となった。

以上、街区単位による建物群類型と下部構造の土地利 用類型、法制度の側面から用途規制指定、及び立地条件 との対応から問題点を抽出し、これらの域構造により、 その特徴と課題を明らかにしてきた。. 今後施行される新
用途規制により、用途地域種目が 8 種目から 12 種目へと 細かな建築規制が為されるが、街区等の建物群という観 点からの地域全体の規制が今後益々必要と考えられる。

拄

1)藍澤 去、津田麻子、齐藤 㴟: 大都市の既成住宅地における土地利用变容 からみた居住地形成要件に関する研究：日本建筮学会計面系論文報告集第 448 号、PP39 48(1993)

2)土地利用が町丁の渻囲て提えられ、且つ土地利用規制が用途地域の菅围てな されているとの前提て、この二つの簛囲が生かせる様に地域の単们を、現在の 町丁目の境界と都市竐画法の用途地域境界とで区切られた籍囲を地区として設 定した。

3)(高見沢实 : 東京都心地区におけろ住機能の存在形孯に関する基磁的考察 都市計画踰文集No26、PP157 162(1991)(2)高过秀興：中心市街地におけ了休用 途の立体的分布の特性に関する研究：都市計画敛文集No24、PP361 366(1989) (3) 日端康雄、安永臣吾 : 東京の都心周辺住宅地の用途混在化之用途別容皘制： 都市計画諭文集No26、PP163 168(1991)(4大方洞一郎、新㛃俊湘、小林重敬 : 幹線街路沿道の立体的土地利用実照に関する研究一東京都目黑通りについて一 都市郡画諭文集№27、PP169 174(1992)(5上田和徳、佐藤践治：階層别床利 用からみた都心部の立体的土地利用解析 : 都市計画詥文集NN25、PP385 390 (1990)(6)岡松昌治、佐藤践治、有馬隆文: 高密度土地利用混合地区におけろ立 体的土地利用の変動に関する研究: 都市計面諭文集NNo28、PP691 696(1993)(7) 王 世踭、尾島俊雄、三浦昌生:立体用途を考慮した階層別驾間利用に関する実 照睭查研究: 日本建築学会胡画系諭文報告集第410号、PP105 112(1990)(8富 田博幸、中出文平：立体的用途構成を考虑した建物利用の实菂及び街区形孯に

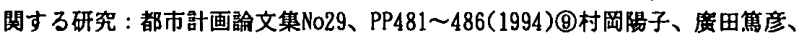
坪井善道 : 東京区部の第一程住居尃用地域をとりまく路楾式用途指定地域にお けろ容箖率充足 : 都市計画詥文集N029、PP487 492(1994)

4)街区とは、建築大事典の定義に基つく道路で四方を囲まれた画地でる。こ れより'90年世田谷区都市計画图において確路し定めた。地区と街区との対応 は地図上て確琶し、クロス分析を行っている。

5)建築大事典 : PP331、橦国社、1986

6)都市計画法第 6 条(都道府県知事は都市計画区域についておおむね 5 年ごと に人口規模・産業分類別の就業人口の規模・市街地の面糟・土地 利用・交通 量等の事項に関する現況及び将来についての調查を行うに基つく、都市計画 に関する基礎調查の一環として位置付けられる。世田谷区ては、東京都実施調 查の作業受託と共に、区独自の調查内容を加えて、現在まてに1981年・1986年 •1991年に実施されている。本研究においては、86年、'91年テータを用いて いろが、建物規模を表す指標については' 86年テータが無いため、建物群類型 钤定にあたっては主に゙91年データのみを用いている。

7)注 1 の䜽文参照

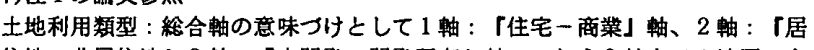
住地一非居住地」 3 軸：「未開発一開発既存」軸。これら 3 軸まての地区の主 成分得点値を、 1 粕に関しては I 型(住宅地中心)、II 型(住商混在)、血型(西 業地中心)、2 蚰に関してはA 型(居住地但位)、B 型(居住地混在)、C型(非居 住地)、3軸に関しては(1)型(開発可能多)(2)型(開発可能少)に区分した(注表 1)。 8)クラマー你数は項目間の関速の強さを表す係数

$\mathrm{C} R \geq 0.01$ の場合に関連ありとみる。

計算式は次の通りである $\mathrm{X} 2$ : カイ二乗值

$\mathrm{CR}=\mathrm{X} 2 / \mathrm{n}(\mathrm{t}-1) \quad \mathrm{n}:$ サンプル

の少ない項目の選択肢の数

$\mathrm{t}:$ 関連する 2 項目の内、選択肢

9)ベースマップは、建物 1 棟毎の建物坐標データより、街区の代表座摆を求め、 作成した。各地図はこの座標に属性を与えることにより得たものでる。

注表 1 土地利用類型の設定

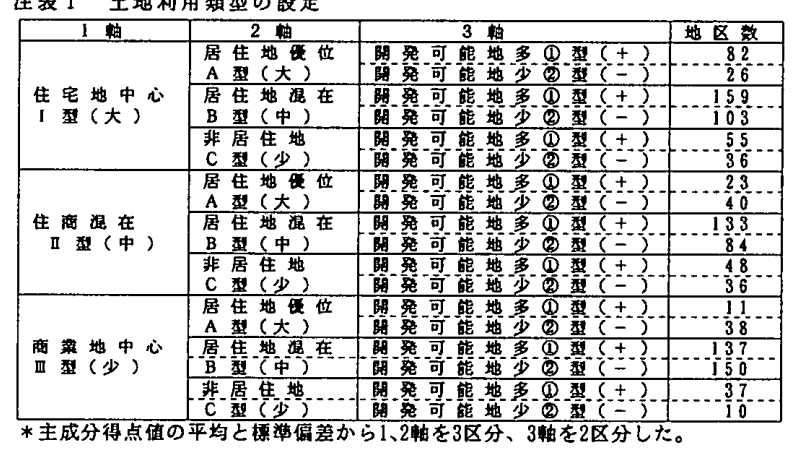

（1994年10月10日原稿受理，1995年 4 月20日採用決定） 